\author{
Anna Michowiak \\ 94-046 Łódź, ul. Armii Krajowej 68 m. 76 \\ tel. (042) 687-09-67, 0602-466-770 \\ annamichowiak@o2.pl
}

\section{WALORYZACJA TURYSTYCZNA GMINY DUBENINKI W ŚWIETLE RÓŻNYCH METOD BADAWCZYCH}

Zarys treści: W artykule przedstawione zostanie przestrzenne zróżnicowanie stopnia atrakcyjności turystycznej gminy Dubeninki. Oparto się na dwóch zasadniczych metodach: zobiektywizowanej metodzie bonitacji punktowej oraz metodzie zindywidualizowanej, wynikającej z percepcji mieszkańców gminy i turystów. Artykuł obejmuje analizę i próbę wyjaśnienia różnic i podobieństw między wynikami poszczególnych prób waloryzacyjnych, jak również ocenę zastosowanych metod.

Słowa kluczowe: waloryzacja turystyczna, waloryzacja przyrodnicza, waloryzacja antropogeniczna, bonitacja punktowa, metoda kwestionariuszowa.

\section{KRÓTKA CHARAKTERYSTYKA BADANEGO OBSZARU}

Gmina Dubeninki (rys. 1) położona jest w powiecie gołdapskim. Zajmuje najbardziej wysunięty na północny wschód obszar w granicach województwa warmińsko-mazurskiego. Przy północno-wschodnim krańcu gminy spotykają się granice Polski, Litwy i Rosji. Do końca II wojny światowej tereny współczesnej gminy Dubeninki przynależały do terytorium pruskiego. W 1945 r. po raz pierwszy znalazły się w granicach Polski.

Pod względem fizycznogeograficznym gmina położona jest w obrębie Pojezierza Litewskiego (KONDRACKI 2002). Zajmuje obszar o powierzchni $205,18 \mathrm{~km}^{2}$. Prawie $40 \%$ powierzchni gminy zajmuje Puszcza Romincka. Pozostałe tereny gminy mają przeważnie charakter rolniczy. W granicach gminy utworzone zostały cztery rezerwaty. Krajobraz gminy cechuje się znacznym urozmaiceniem terenu, charakterystycznym dla obszarów młodoglacjalnych. W przestrzeni wyróżniają się liczne wzgórza kemowe (najwyższe 295,4 m n.p.m.), ko-

\section{AN EVALUATION OF TOURISM IN THE GMINA OF DUBENINKI USING DIFFERENT RESEARCH METHODS}

Abstract: The article presents the spatial differentiation of tourism attractiveness in the gmina of Dubeninki. The author uses two basic methods: an objective ranking method, and an individualised ranking method based on the perceptions of the gmina's inhabitants and tourists. The article includes an attempt to analyse and explain the differences and similarities between the results as well an evaluation of the methods themselves.

Key words: tourism evaluation, environmental evaluation, anthropogenic evaluation, ranking, questionnaire method.

\section{A SHORT DESCRIPTION OF THE STUDIED AREA}

The gmina of Dubeninki (fig. 1) in the Goldapski Powiat occupies the most north-eastern area of the WarminskoMazurskie Województwo. At its own north-eastern end there is a point where the borders of Poland, Lithuania and Russia meet. Until the end of World War II the area of the contemporary gmina was in Prussian territory and in 1945 was incorporated into Poland.

The gmina lies within the Lithuanian Lake District (KONDRACKI 2002) and covers an area of $205.18 \mathrm{~km}^{2}$, almost $40 \%$ of which is the Romincka Forest. The remainder is mostly agricultural and there are four nature reserves within its borders. The landscape is varied, typical of recently glaciated areas, with distinctive elements such as kames (the highest reaching $295.4 \mathrm{~m}$ 
tły wytopiskowe, moreny czołowe, niewielkie powierzchniowo równiny sandrowe oraz wyraźne rynny polodowcowe. $\mathrm{O}$ urozmaiconej rzeźbie terenu świadczyć mogą znaczne deniwelacje osiagające maksymalnie $70 \mathrm{~m} / \mathrm{km}^{2}$ w rejonie Maciejowięt (przełom Błędzianki). Istotnym elementem krajobrazu są torfowiska oraz liczne rozległe rozlewiska bobrowe znajdujące się na obszarze puszczy i jej przedpolach. Występujące jeziora mają na ogół założenia wytopiskowe lub rynnowe. Sieć rzeczna jest słabo rozwinięta. Środowisko przyrodnicze gminy jest przekształcone w niewielkim stopniu, cechuje się wysokimi wskaźnikami czystości oraz względnie dużą odpornością na antropopresję. Walory przyrodnicze gminy Dubeninki odgrywają zatem istotną rolę w kształtowaniu atrakcyjności tych terenów. above sea level), kettle holes, end moraines, small outwash plains and distinctive post-glacial gullying as well as steep slopes, near Maciejowięta (the Błędzianka ravine). Bogs are an important element of the landscape as are the extensive beaver ponds in the forest and surrounding areas. The lakes usually originate in kettle holes or surface depressions and the river system is poorly developed. The natural environment has not been transformed much, it is very clean and relatively resistant to harmful human activity and plays a significant role in terms of the area's attractiveness.

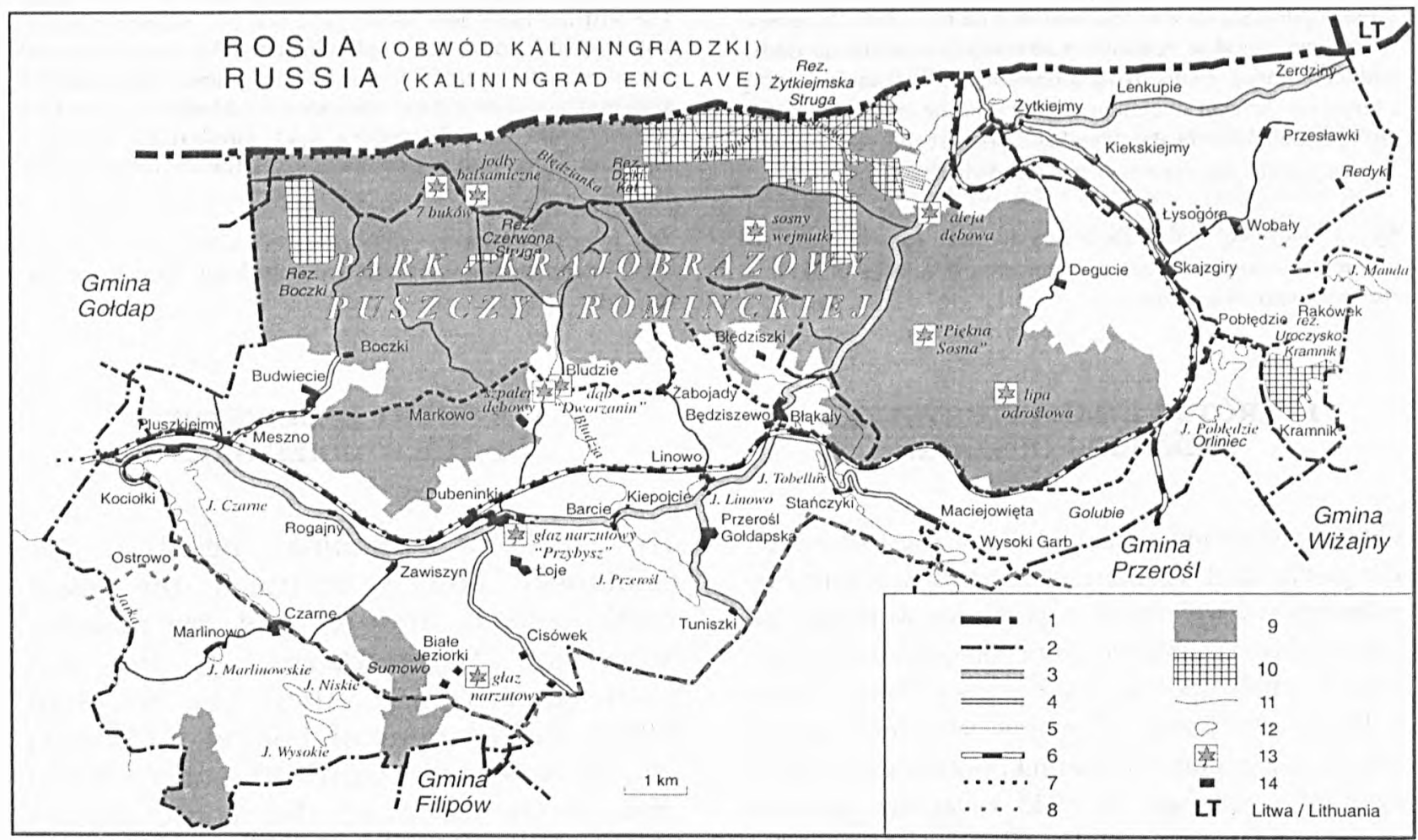

Rys. 1. Mapa ogólnogeograficzna gminy Dubeninki (ż ró d ł o: opracowanie własne)

1- granica państwowa, 2 - granice gmin, 3 - droga krajowa, 4 - droga drugorzędna, 5 - droga lokalna, 6 - nieczynna linia kolejowa, 7 - granica parku krajobrazowego, 8 - granica otuliny parku, 9 - las, 10 - rezerwat przyrody, 11 - rzeka, 12 - jezioro, 13 - pomnik przyrody, 14 - zabudowa wsi

Fig. 1. Map of the gmina of Dubeninki (s o u r c e: author)

1 - state border, 2 - gmina borders, 3 - main road, 4 - secondary road, 5 - local road, 6 - unused railway line, 7 - landscape park boundary, 8 - landscape park buffer zone, 9 - forest, 10 - nature reserve, 11 - river, 12 - lake, 13 - natural monument, 14 - village buildings

Gmina Dubeninki jest gminą słabo zaludnioną $\left(17 \mathrm{osób} / \mathrm{km}^{2}\right)$. Z wyjątkiem dwóch największych wsi wielodrożnicowych - Żytkiejm i Dubeninek pozostałe mają zwykle charakter przysiółków bądź
The gmina of Dubeninki is sparsely populated $\left(17 / \mathrm{km}^{2}\right)$ and apart from the two largest villages, Żytkiejmy and Dubeninki, the remaining are hamlets 
przekształconych ulicówek o luźnej zabudowie. Walorami architektonicznymi odznacza się budownictwo leśne oraz pozostałości po zespołach dworsko-parkowych. W krajobrazie wyróżniają się ponadto XIX-wieczne cmentarze ewangelickie (na terenie gminy jest ich ponad 60 ). Oryginalnym walorem są tzw. głazy Wilhelma, pomniki upamiętniające polowania na jelenie cesarza Wilhelma II oraz pozostałości wału Ericha Kocha, ciagu umocnień obronnych z 1944 r. Ważną atrakcję gminy stanowi dawna linia kolejowa Gołdap-Gusiew z zachowanymi dworcami, mostami i wiaduktami. Najistotniejszą dominantą turystyczną gminy, skupiającą największy ruch turystyczny, są podwójne mosty kolejowe w Stańczykach z początku $\mathrm{XX} w$.

\section{ATRAKCYJNOŚĆ TURYSTYCZNA GMINY W ŚWIETLE METODY BONITACJI PUNKTOWEJ}

Atrakcyjność turystyczna jest pojęciem względnym. Dlatego do przedstawienia problemu atrakcyjności autorka posłużyła się metodami badawczymi przy zastosowaniu różnych kryteriów i metod pomiaru oraz z punktu widzenia różnych zbiorowości oceniających.

W celu dokonania zobiektywizowanej oceny waloryzacji turystycznej obszaru gminy posłużono się metodą bonitacji punktowej, będącej najczęściej stosowaną metodą oceny przydatności danego obszaru dla potrzeb turystyki (RADZIEJOWSKI 1979). Problemem tym zajmowali się m.in. BARTKOWSKI (1965, 1969), WARSZYŃSKA (1970, 1974), MARSZ (1970), czy RADZIEJOWSKI (1979). W pracach wymienionych autorów głównym kryterium determinującym końcową ocenę jest atrakcyjność przyrodnicza danego terenu, w mniejszym zaś stopniu ranga walorów pozaprzyrodniczych oraz zagospodarowanie turystyczne. Sporą uwagę autorzy poświęcali również zagadnieniu dostępności komunikacyjnej.

W zamyśle autorki opracowania było jednak stworzenie waloryzacji badanego obszaru opartej wyłącznie na walorach turystycznych, z celowym pominięciem zagospodarowania oraz dostępności komunikacyjnej. Takie działanie miało posłużyć uzyskaniu jak najwierniejszego obrazu atrakcyjności krajobrazowej gminy, nie uwzględniając stopnia dostosowania danego rejonu do obsługi ruchu turystycznego.

Przy dokonywaniu bonitacji oprócz danych z mapy wykorzystane zostały ponadto informacje pocho- with sparsely scattered housing. Forest buildings and the remains of manors and their parks are valuable architectural resources while evangelical cemeteries are a distinctive landscape element (over 60 in the gmina). Kaiser Wilhelm's boulders - monuments commemorating Wilhelm II's stag hunts - and the remains of Erich Koch's defensive fortifications from 1944 are also of interest. Another attraction is the former railway line between Gołdap and Gusiew with wellpreserved stations, bridges and viaducts including the most important tourist attraction of the gmina, the double railway viaducts at Stańczyki from the beginning of the $20^{\text {th }}$ century.

\section{THE TOURIST ATTRACTIVENESS OF THE GMINA ACCORDING TO RANKING METHODS}

Tourist attractiveness is a relative notion. Therefore, in order to present it, the author used research models, applying different criteria and measuring methods, from the points of view of different evaluating groups.

In order to evaluate tourism objectively, methods involving ranking are used most frequently (RADZIEJOWSKI 1979), an approach which had been discussed earlier by BARTKOWSKI (1965, 1969), WARSZYŃSKA (1970, 1974), MARSZ (1970) and RADZIEJOWSKI (1979). In their works the main criterion which determined the final evaluation was natural attractiveness, and to a lesser extent non-natural resources as well as tourism infrastructure. These authors also considered transport accessibility, however the author of the present article aimed at an evaluation based solely on tourism resources intentionally disregarding infrastructure and accessibility. As a result the focus is on landscape attractiveness regardless of tourism infrastructure.

Apart from information from maps the author gathered data directly, and this was given priority when a discrepancy occurred between a map and 
dzące $\mathrm{z}$ bezpośredniej inwentaryzacji, które traktowane były priorytetowo $\mathrm{w}$ przypadku rozbieżności między treścią mapy a stanem faktycznym.

Bazę do stworzenia siatki pól podstawowych stanowiła siatka kartograficzna mapy $w$ skali 1: 25 000. Obszar gminy Dubeninki podzielony został na 71 kwadratowych pól podstawowych o powierzchni $4 \mathrm{~km}^{2}$ każde. Polom podstawowym nadane zostały oznaczenia literowo-numeryczne (w pionie od $\mathrm{A}$ do $\mathrm{H}$, w poziomie od 1 do 13 ).

Każdemu z pól przypisana została odpowiadajaca mu liczba punktów bonitacyjnych uzyskanych w drodze przeprowadzania obliczeń. Autorka zaproponowała kryteria opisujące krajobraz klasyfikując je w cztery zasadnicze grupy: walory przyrodnicze, walory dóbr kultury materialnej, walory widokowe oraz elementy obniżające atrakcyjność. Walory oceniane były dodatnio, w skali od 1 do 10 punktów, natomiast elementy obniżające atrakcyjność - ujemnie, od -4 do -1 punktu.

Stopień atrakcyjności terenu rozpatrzono w trzech aspektach: atrakcyjność przyrodnicza (suma punktów za walory przyrodnicze), atrakcyjność antropogeniczna (suma punktów za walory dóbr kultury materialnej) oraz atrakcyjność kompleksowa (obejmująca sumę punktów za wszystkie rozważane kryteria, uwzględniając również elementy obniżające atrakcyjność).

\subsection{WALORYZACJA TURYSTYCZNO- -PRZYRODNICZA}

W wyniku przeprowadzenia waloryzacji przyrodniczej uzyskano wartości bonitacyjne w polach podstawowych z przedziału od 3 do 30 punktów. Dokonano następującej klasyfikacji stopnia atrakcyjności turystyczno-przyrodniczej: 0-6pkt. - tereny o małej atrakcyjności, 7-12 pkt. - tereny o średniej atrakcyjności, 13-18 pkt. - tereny o dużej atrakcyjności,

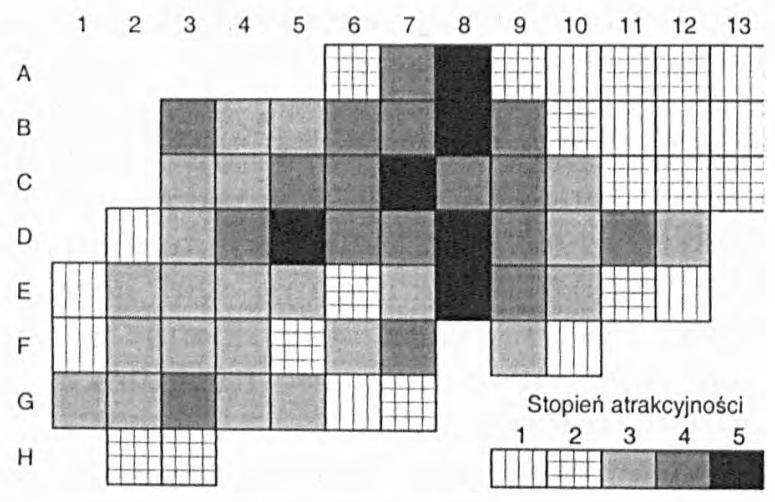

Rys. 2. Waloryzacja turystyczno-przyrodnicza obszaru gminy Dubeninki (opracowanie własne na podstawie przeprowadzonych badań) 1 - mały, 2 - średni, 3 - duży, 4 - bardzo duży, 5 - wybitny the actual situation on the ground. A 1 : 25000 map was the basis for creating a grid and the gmina was divided into 71 squares (each $4 \mathrm{~km}^{2}$ ) - marked vertically from $\mathrm{A}-\mathrm{H}$ and horizontally from 1-13. For each square a point score was calculated. The author proposed four groups of resource criteria for classifying the landscape: natural, cultural, visual and also depreciatory elements. They were evaluated positively on a scale from $1-10$ and for depreciatory elements, negatively from -1 to -4 . Attractiveness was considered in three ways: natural (scores for natural resources), anthropogenic (scores for cultural resources) and overall (scores for all criteria including depreciatory elements).

\subsection{NATURAL RESOURCE EVALUATION}

Scores for natural resources ranged from 3 to 30 giving the following classification for natural attractiveness: 0-6 - low, 7-12 - medium, 13-18 high, 19-24 - very high, 25-30 exceptional. Twelve squares (17\%) had low attractiveness, $13(19 \%)$ - medium, $23(32 \%)$ - high, 17 (24\%) - very high and $6(8 \%)$ - exceptional. The distribution is illustrated in fig. 2 .

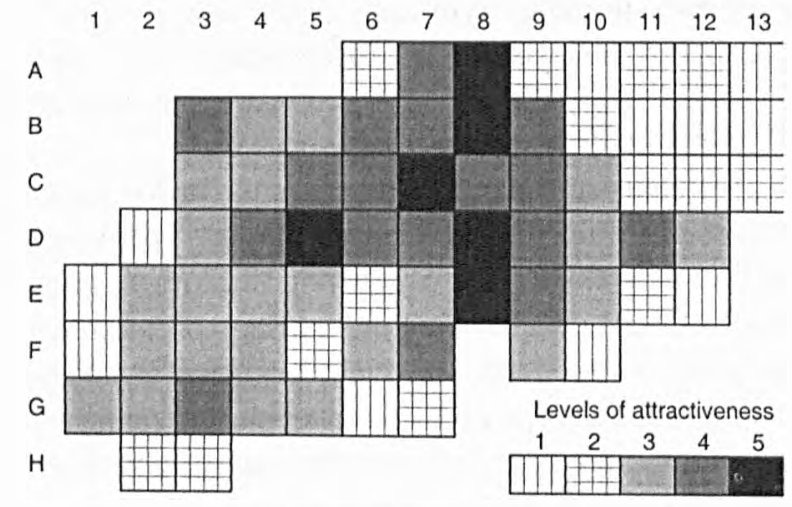

Fig. 2. Natural resource evaluation (s o u r c e: author based on research)

1 -low, 2 - medium, 3 - high, 4 - very high, 5 - exceptional 
19-24 pkt. - tereny o bardzo dużej atrakcyjności, 25-30 pkt. - tereny o wybitnej atrakcyjności. Tereny o małej atrakcyjności objęły obszar 12 pól podstawowych (17\%), o średniej - 13 pól (19\%), o dużej - 23 pola (32\%), o bardzo dużej - 17 pól (24\%), zaś o wybitnej - sześć pól (8\%). Rozłożenie stopnia atrakcyjności ilustruje rys. 2 .

Najmniej atrakcyjne przyrodniczo okazały się rejony północno-wschodniej części gminy. Są to tereny rolnicze, bezleśne, o umiarkowanych deniwelacjach, rzędu $20 \mathrm{~m}$. W rejonie tym występuje tylko jedno większe jezioro, $\mathrm{z}$ kolei płynące rzeki nie stanowią o atrakcyjności. Ponadto najniższe wartości uzyskały skrajnie położone pola, przy południowo-wschodniej i zachodniej granicy gminy. Na ich niską wartość, oprócz czynników podobnych do opisanych w poprzednim przypadku, wpłynęła również mała powierzchnia rozpatrywanego terenu (często mniejsza od $1 \mathrm{~km}^{2}$ ).

Tereny o dużej atrakcyjności przyrodniczej znajdują się w zachodniej i południowej części gminy. Walorami przyrodniczymi determinującymi ocenę były w przypadku okolic Budwieć i terenów na północ od wsi - duże obszary leśne (Puszcza Romincka), w przypadku rejonu Pluszkiejm i Marlinowa wysoka jeziorność, zaś w przypadku okolic Zawiszyna i Cisówka - znaczne deniwelacje, rzędu 30-40 m, oraz lesistość. We wschodniej części gminy dużym stopniem atrakcyjności wyróżniły się okolice na północ i południe od Deguć, ze względu na usytuowanie na skraju puszczy.

Środkowa część gminy obejmująca znaczne obszary Puszczy Rominckiej zaklasyfikowana została do terenów o bardzo dużej atrakcyjności. Oprócz waloru w postaci dużego kompleksu leśnego na ocenę wpłynęła również sieć rzeczna oraz utworzone na tych terenach rezerwaty przyrody. Ponadto do tej grupy zaliczono pojedyncze pola obejmujące północno-zachodni skraj gminy (Puszcza Romincka, rezerwat, rozlewisko bobrów), tereny wokół jezior: Niskiego i Wysokiego, Przerośl oraz Pobłędzie (obszary zalesione, duże deniwelacje, obecność wód stojących).

Do obszarów o wybitnych walorach przyrodniczych zaliczono tereny wokół Stańczyk, Błąkał oraz Będziszewa. Zadecydowały o tym elementy krajobrazu wyróżniające te rejony spośród pozostałych: przełomowy odcinek Błędzianki, deniwelacje sięgające $70 \mathrm{~m}$, a także zwarty obszar leśny. Również wysoko ocenione zostały obszary na terenie puszczy, w rejonie Zacisza (rezerwat ,Żytkiejmska Struga") i Wilczej Góry (duże deniwelacje). Wysoko został oceniony rejon Bludzi Wielkich.
The north-eastern parts of the gmina turned out to be the least attractive. These are forestless farming areas with marked changes of level (in the region of 20 metres), there is only one large lake and the rivers are not an attractiveness factor. The squares at the extreme south-eastern and western borders had the lowest scores because of their small area (often less than one $\mathrm{km}^{2}$ ) as well as the factors described above.

The highly attractive areas in the western and southern parts were determined by vast forested areas - the Romincka Forest (Budwiecie and areas north of the village), numerous lakes (around Pluszkiejmy and Marlinowo), as well as considerable changes in level $(30-40 \mathrm{~m})$ and forests (Zawiszyno and Cisowek). In the eastern part of the gmina, the areas north and south of Degucie were seen as highly attractive due to their location at the edge of the forest.

The central part of the gmina, covering a large section of the Romincka Forest, was classified as very highly attractive and in addition to the very large forested area, the river system and nature reserves influenced the evaluation. This group also included single squares at the north-western end of the gmina (the Romincka Forest, a nature reserve, beaver ponds), and areas around Lakes Niskie, Wysokie, Przerośl and Pobłędzkie (forest, steep slopes, stagnant water).

Areas around Stańczyki, Błakały and Będziszewo were considered exceptionally attractive due to distinguishing landscape elements: the Błędzianka ravine, changes of level of up to $70 \mathrm{~m}$, as well as dense forest. Areas in the forest near Zacisze (the 'Żytkiejmska Struga' reserve) and Wilcza Góra (steep slopes) were also highly evaluated, likewise Bludzie Wielkie. 


\subsection{WALORYZACJA TURYSTYCZNO- -ANTROPOGENICZNA}

Walory dóbr kultury materialnej nie odznaczają się w krajobrazie ciągłością, mają charakter punktowy (cmentarze, wiadukty) lub liniowy (torowisko, wał Ericha Kocha). Z tego faktu wynika specyficzne rozłożenie stopnia atrakcyjności - pola o wysokich wartościach sąsiadują z polami o wartościach minimalnych. Zauważa się oczywistą prawidłowość w rozłożeniu walorów antropogenicznych, które koreluje z rozmieszczeniem sieci osadniczej oraz przebiegiem ciągów komunikacyjnych - drogą krajową i dawną linią kolejową.

W wyniku bonitacji, pola pozbawione osadnictwa w wielu przypadkach uzyskiwały wartość zerową. Najwyższą wartością w obrębie jednego pola było 20 punktów. Dokonano następującej klasyfikacji stopnia atrakcyjności antropogenicznej: 0 pkt. tereny nieatrakcyjne, 1-4 pkt. - tereny o małej atrakcyjności, 5-8 pkt. - tereny o średniej atrakcyjności, 9-12 pkt. - tereny o dużej atrakcyjności, 1316 pkt. - tereny o bardzo dużej atrakcyjności, 17-20 pkt. - tereny o wybitnej atrakcyjności. Tereny pozbawione walorów dóbr kultury materialnej objęły 23 pola ( $32 \%$ obszaru), do grupy terenów o małej atrakcyjności zaliczono obszar 32 pól podstawowych $(45 \%)$, o średniej - siedem pól $(10 \%)$, o dużej - cztery pola $(6 \%)$, o bardzo dużej - cztery pola $(6 \%)$, zaś o wybitnej tylko jedno (1\%). Rozłożenie stopnia atrakcyjności antropogenicznej ilustruje rys. 3 .

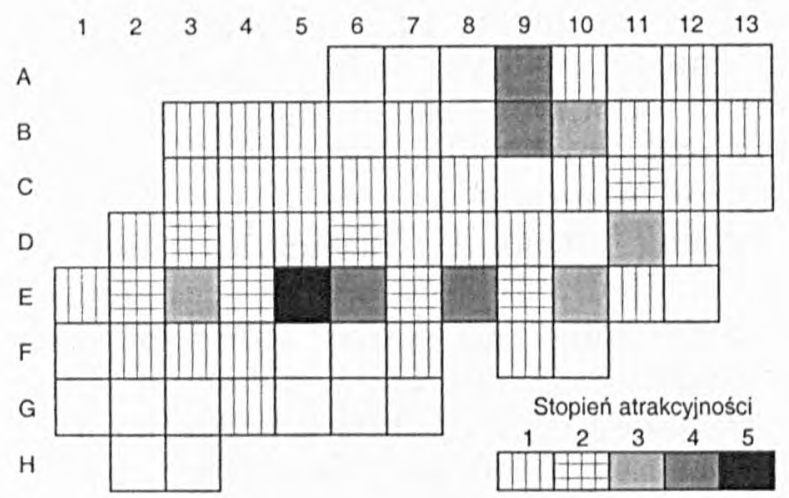

Rys. 3. Waloryzacja turystyczno-antropogeniczna obszaru gminy Dubeninki (opracowanie własne na podstawie przeprowadzonych badań) 1 - mały, 2 - średni, 3 - duży, 4 - bardzo duży, 5 - wybitny

Największą grupę utworzyły pola o małym stopniu atrakcyjności. Są one rozłożone dość równomiernie na obszarze gminy. Obejmują osady, w których zachowały się cmentarze ewangelickie, jak

\subsection{ANTHROPOGENIC RESOURCE EVALUATION}

Cultural resources do not occur in sequences in the landscape but appear as points (e.g. cemeteries and viaducts) or lines (e.g. railways or Erich Koch's defensive fortifications) resulting in a distribution where squares of high attractiveness are found next to low. There is an obvious regularity in the distribution of anthropogenic resources correlating with the layout of the settlement system and also the transport routes which include a national trunk road and a former railway.

Squares without settlement often did not score any points but the highest was 20 giving the following classification for cultural attractiveness: 0 - unattractive areas, 1-4-low, 5-8-medium, 9-12 - high, 13-16 - very high, 1720 - exceptional. No cultural resources were recorded in 23 squares (32\%), 32 squares (45\%) had low attractiveness, seven $(10 \%)$ - medium, four $(6 \%)$ high, four $(6 \%)$ - very high, and one (1\%) - exceptional. The distribution is illustrated in fig. 3.

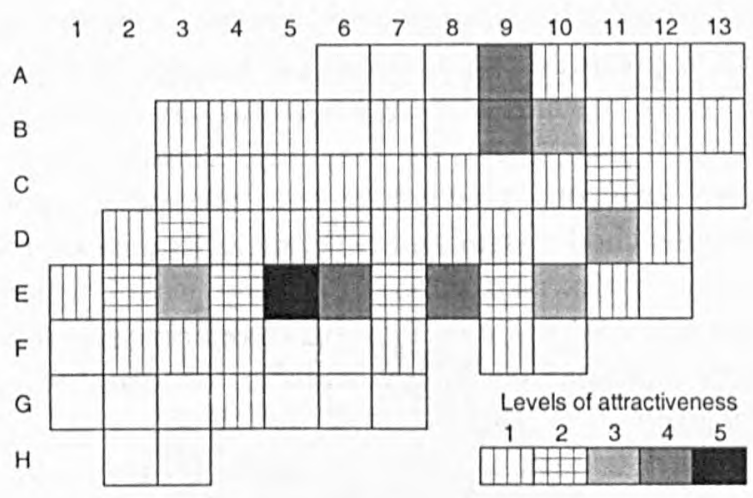

Fig. 3. Anthropogenic resource evaluation (s o u r c e: author based on research)

1 - low, 2 - medium, 3-high, 4 - very high, 5 - exceptional

Areas of low attractiveness dominated and were distributed quite evenly throughout the gmina, including settlements with evangelical cemeteries as 
również tereny leśne z głazami Wilhelma bądź innymi pomnikami.

Tereny o średniej, dużej oraz bardzo dużej atrakcyjności zlokalizowane są wzdłuż odcinka drogi krajowej między Pluszkiejmami a Błąkałami, a następnie wzdłuż dawnej linii kolejowej na odcinku Błąkały-Żytkiejmy. O atrakcyjności zadecydowały tu zabytki architektury i budownictwa zlokalizowane na terenach wsi oraz poza nimi (wiadukty i mosty, dworce kolejowe). W obrębie tego pasa wyróżniono cztery pola o dużym stopniu atrakcyjności: Pluszkiejmy i okolice, teren dawnej wsi Golubie, Pobłędzie i okolice, a także rejon Kiekskiejm. Za tereny najatrakcyjniejsze uznano rejon Dubeninek i Kiepojć oraz Żytkiejmy, gdzie walory dóbr kultury materialnej występuja w dużym nagromadzeniu i cechują się znaczną różnorodnością. Wysoko ocenione zostały ponadto Stańczyki. W tym przypadku ewidentnym walorem były mosty kolejowe, walorami uzupełniającymi stały się natomiast torowisko, pozostałe okoliczne wiadukty, a także cmentarz ewangelicki.

\subsection{WALORYZACJA TURYSTYCZNA KOMPLEKSOWA}

Po zestawieniu walorów przyrodniczych, antropogenicznych oraz nie uwzględnianych w dwóch poprzednich próbach waloryzacyjnych elementów widokowych i elementów obniżających atrakcyjność uzyskano obraz waloryzacji turystycznej całościowej terenu gminy. Przedstawiony on został na rys. 4.

Minimalna wartość łączna w obrębie jednostki podstawowej wyniosła 1 pkt - wartość taką uzyska- well as forested areas with Kaiser Wilhelm's boulders and other monuments.

Areas of medium, high and very high attractiveness are situated along the section of the main road between Pluszkiejmy and Blakkały, and the former railway line between Błąkały and Żytkiejmy. Their attractiveness was determined by architectural monuments both in villages and outside (viaducts, bridges and railway stations). Four squares of high attractiveness were identified: Pluszkiejmy and its vicinity, the area of the former village of Golubie, Pobłędzie and its vicinity, and the region of Kiekskiejmy. Dubeninki and Kiepojcie, as well as Żytkiejmy, with a great number of different cultural resources, were considered the most attractive. Stanczyki was also highly evaluated with its obvious resource of railway viaducts, followed by the railway line, the remaining bridges and its evangelical cemetery.

\subsection{OVERALL RESOURCE EVALUATION}

From both natural and anthropogenic resources, as well as the visual and depreciatory elements not considered previously, the author arrived at an overall resource evaluation for the gmina, presented in fig. 4.

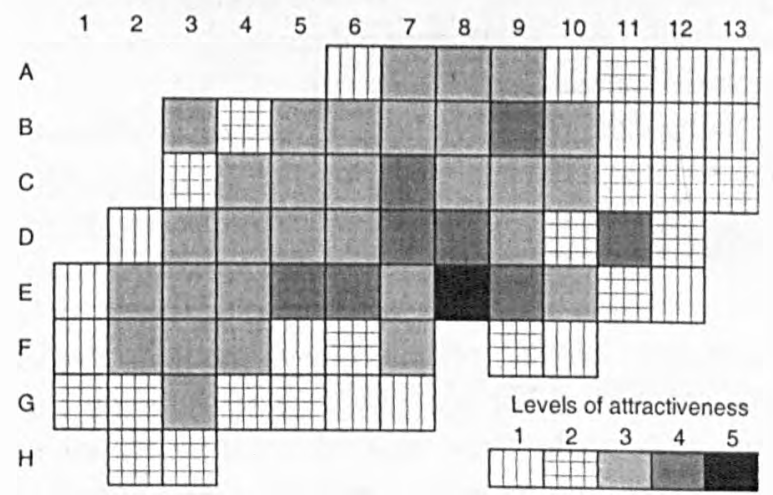

Fig. 4. Overall resource evaluation

(s o u r c e: author based on research)

1-low, 2 -medium, 3-high, 4-very high, 5 - exceptional 
ło jedno pole; maksymalna 50 punktów, która również wystapiła jednokrotnie. Ustalono pięć przedziałów bonitacyjnych: 1-9 pkt. - tereny o małej atrakcyjności, 10-19 - tereny o średniej atrakcyjności, 2029 - tereny o dużej atrakcyjności, 30-39 - tereny o bardzo dużej atrakcyjności i 40-50 pkt. - tereny o wybitnej atrakcyjności. Udział pól w poszczególnych grupach bonitacyjnych przedstawia się następująco: tereny o małej atrakcyjności - 15 pól $(21 \%)$, średniej - 17 (24\%), dużej - 30 (42\%) i bardzo dużej-osiem pól (11\%) i o wybitnej-jedno pole (1\%).

Decydujący wpływ na ogólną ocenę atrakcyjności miały walory przyrodnicze. Wynika to choćby z faktu, że mapa waloryzacyjna całościowa jest zbliżona do wyniku waloryzacji przyrodniczej. Niemniej jednak nałożenie na mapę przyrodniczą walorów dóbr kultury materialnej oraz pozostałych dwóch kategorii elementów zdecydowanie obniżyło ogólną atrakcyjność obszaru gminy. Spośród 71 pól połowa (35 pól) zaklasyfikowała się do niższej klasy bonitacyjnej, a zaledwie w przypadku czterech jednostek walory antropogeniczne i widokowe spowodowały ogólny wzrost atrakcyjności.

Największą rozbieżność obserwuje się w polu E6, w którym występują walory antropogeniczne o dużym znaczeniu, zaś walory przyrodnicze nie odgrywają istotnej roli. Podobna sytuacja występuje w polu sąsiednim, E5. Pola te odpowiadają w terenie obszarowi wsi Dubeninki i jej najbliższym okolicom. Wynika to z pewnej prawidłowości w rozmieszczeniu walorów przyrodniczych i pozaprzyrodniczych w przestrzeni. Walory antropogeniczne wiążą się z siecią osadniczo-komunikacyjną gminy, $\mathrm{z}$ kolei walory przyrodnicze koncentrują się na obszarach nie objętych osadnictwem, takich jak Puszcza Romincka czy rejony położone z dala od szlaków komunikacyjnych. Można zatem mówić o wzajemnym uzupełnianiu się rozmieszczenia poszczególnych walorów.

W ogólnej klasyfikacji najmniej korzystnie wypadły obszary północno-wschodniej i wschodniej części gminy oraz obszary skrajnie położone, w części południowej i zachodniej.

Najbardziej rozległy obszar gminy zaklasyfikowany został do przedziału pól o dużej atrakcyjności. Obszary o bardzo dużym stopniu atrakcyjności objęły rejon Dubeninek i Kiepojć. W obrębie tej klasy bonitacyjnej znalazły się ponadto dwa pojedyncze pola obejmujące obszar południowo-wschodniej części Żytkiejm wraz z Kiekskiejmami, a także rejon Pobłędzia. Zdecydowanie najatrakcyjniejszym polem jest pole E8 obejmujące wieś Stańczyki z zabytkowymi mostami, fragment rynny Błędzianki oraz jezioro Tobellus.
The minimum score was 1 (one square only) and the maximum - 50 (also a single square). The attractiveness categories were: 1-9 - low, 1019 - medium, 20-29 - high, 30-39 very high, 40-50 - exceptional. Areas of low attractiveness covered 15 squares $(21 \%)$, medium - 17 (24\%), high - 30 $(42 \%)$, very high - eight $(11 \%)$ and exceptional - one (1\%).

That natural resources controlled the overall evaluation was shown by the close correspondence of the overall map with that for natural resources. However, cultural resources and the other two categories significantly decreased the overall attractiveness of the gmina. Out of 71 squares, half (35) were reclassified into a lower ranking category, and only in four squares did anthropogenic and visual resources increase overall attractiveness.

The largest divergence was in square E6 where there are significant anthropogenic resources although natural resources do not play an important role (the situation is similar in the adjacent square, E5). These squares correspond to Dubeninki and its immediate vicinity and are a product of patterns in the distribution of natural and non-natural resources. Anthropogenic resources are related to the settlement system of the gmina, while natural resources occur in areas outside it such as Romincka Forest or regions far from transport routes.

In the overall classification, the northeastern and eastern parts of the gmina, as well as areas in the extreme southern and western parts, were evaluated lowest. The largest part was of high attractiveness with Dubeninki and Kiepojcie proving areas of very high attractiveness. In this category also were individual squares, one in the south-eastern part of Żytkiejmy (together with Kiekskiejmy, as well as another in the region of Pobłedzie. The most attractive square was E8 covering the village of Stanczyki with its historic viaducts, a part of the Błedzianka ravine and Lake Tobellus. 


\section{ATRAKCYJNOŚĆ TURYSTYCZNA GMINY W POSTRZEGANIU MIESZKAŃCÓW I TURYSTÓW}

Na podstawie przeprowadzonych wywiadów kwestionariuszowych z mieszkańcami gminy oraz z turystami dokonano próby szczegółowej oceny stopnia atrakcyjności krajobrazu badanego obszaru z punktu widzenia tych dwóch zbiorowości. Zebraniu niezbędnych informacji posłużyły także załączone do ankiety schematyczne mapy obszaru gminy. Respondentów pytano o obiekty i obszary na terenie gminy ich zdaniem najbardziej atrakcyjne turystycznie. Proszono również o zaznaczanie miejsc na mapie.

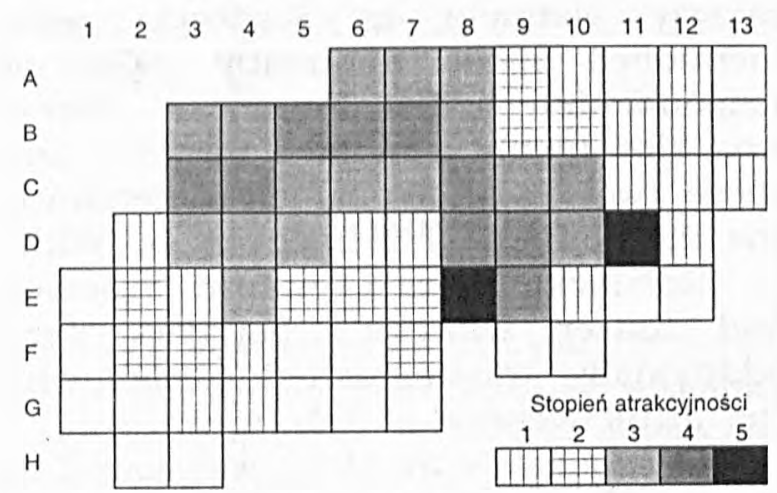

Rys. 5. Waloryzacja obszaru gminy Dubeninki w postrzeganiu mieszkańców (opracowanie własne na podstawie przeprowadzonych badań) 1 - mały, 2 - średni, 3 - duży, 4 - bardzo duży, 5-wybitny

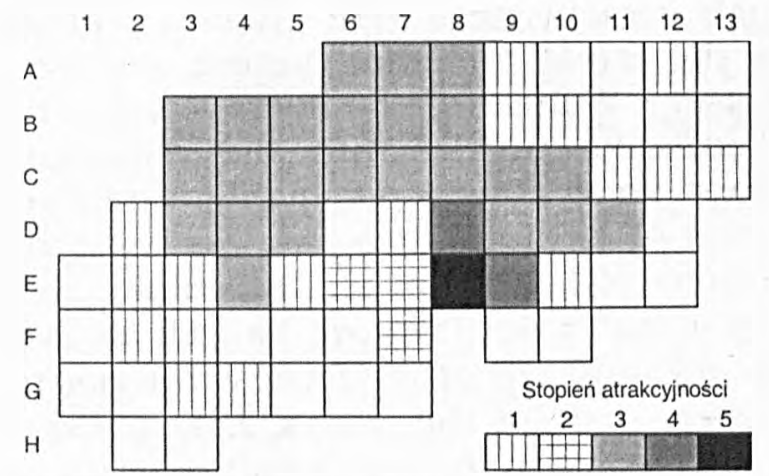

Rys. 6. Waloryzacja obszaru gminy Dubeninki w postrzeganiu turystów (opracowanie własne na podstawie przeprowadzonych badań) 1 - mały, 2 - średni, 3 - duży, 4 - bardzo duży, 5 - wybitny, 6 - obszar nieatrakcyjny

Przy dokonywaniu analizy ankiet stopień atrakcyjności waloru mierzony był ilościowo. Wielokrotne wymienienie przez kolejnych respondentów określonego waloru stanowiło o jego wysokiej atrakcyjności; nie brano pod uwagę cech jakościowych. Następnie każdemu walorowi przypisywano liczbę

\section{THE TOURIST ATTRACTIVENESS OF THE GMINA AS PERCEIVED BY INHABITANTS AND TOURISTS}

Based on a questionnaire survey conducted among gmina inhabitants and tourists, an attempt to evaluate landscape attractiveness was made from the perspectives of these two groups. Outline maps of the gmina were enclosed with the questionnaires to help collect the necessary information. Respondents were asked to name the sites and areas which they considered the most attractive and to mark them on the maps.

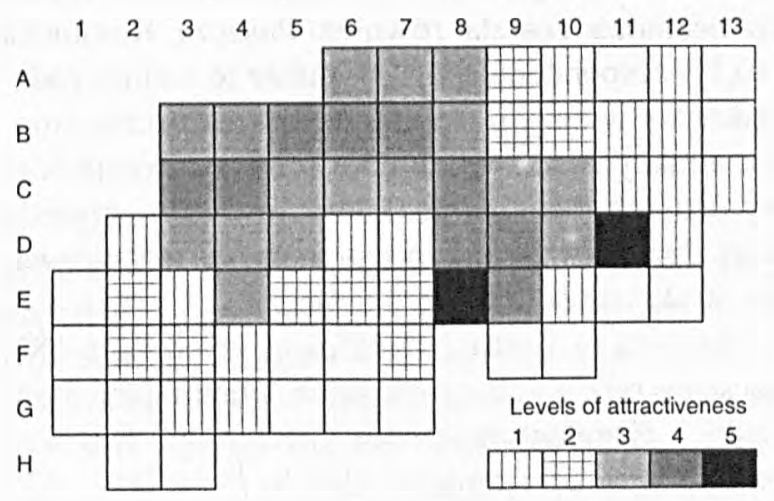

Fig. 5. Evaluation in the perception of inhabitants (s o u r c e: author based on research)

1-low, 2 - medium, 3 - high, 4 - very high, 5 - exceptional

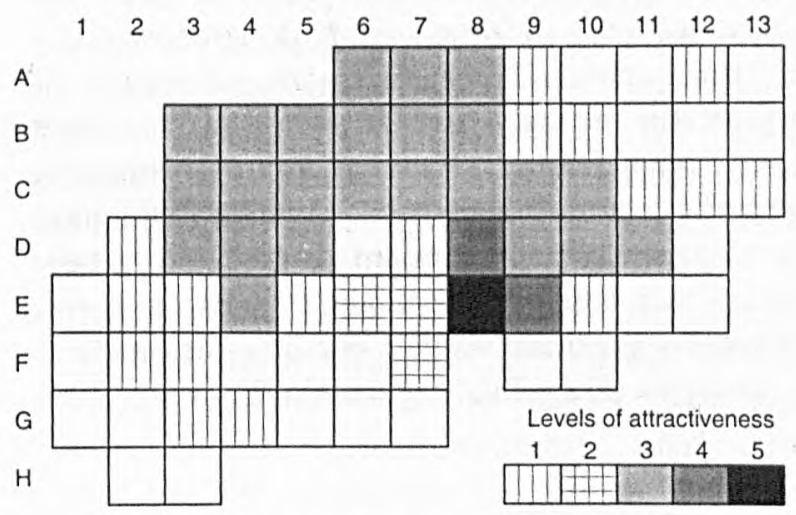

Fig. 6. Evaluation in the perception of tourists (s o u r c e: author based on research)

1-low, 2 - medium, 3 - high, 4 - very high, 5 - exceptional, 6 - unattractive area

While analysing the questionnaires the attractiveness of a resource was measured quantitatively so those 
punktów odpowiadającą liczbie osób, które ten walor wymieniły w swojej ankiecie. Na mapie z siatką kwadratów zlokalizowano miejsca występowania poszczególnych walorów, polom tym nadano odpowiednią wartość punktową. Jeżeli w pojedynczym polu występował więcej niż jeden walor, liczbę punktów przypadająca na poszczególne walory sumowano. Uzyskano w ten sposób mapę waloryzacji wynikającą z percepcji mieszkańców oraz drugą odnoszącą się do percepcji turystów (rys.5, 6).

\subsection{PERCEPCJA MIESZKAŃCÓW GMINY}

Mieszkańcy wymienili łącznie 36 walorów na terenie gminy Dubeninki. Najczęściej wymienianymi były dawne mosty kolejowe w Stańczykach. Podane one zostały przez $93 \%$ respondentów. Wysoko oceniona została również Puszcza Romincka (40,1\% respondentów). To właśnie te walory zadecydowały w dużym stopniu o rozmieszczeniu stopnia atrakcyjności. W obrębie Puszczy Rominckiej wyróżnione zostały dodatkowo rezerwaty przyrody oraz głazy Wilhelma, co wpłynęło na zróżnicowanie atrakcyjności na tym terenie.

Najwyższą wartość punktową, wynoszącą 181, uzyskało pole z oznaczeniem E8, obejmujące Stańczyki i fragment przełomu Błędzianki. Również bardzo wysoko ocenione zostało pole D11 (125 pkt.), o czym zadecydowało sąsiedztwo jeziora Pobłędzie i Puszczy Rominckiej. Tereny bardzo atrakcyjne objęły obszary w obrębie puszczy $z$ rezerwatami przyrody, głazami Wilhelma oraz przełomem Błędzianki. Pozostałe obszary w tym kompleksie leśnym zaliczone zostały do terenów o dużej atrakcyjności. Terenami średnio atrakcyjnymi turystycznie okazały się, zdaniem mieszkańców gminy, rejon Jeziora Czarnego, rejon Dubeninek, Kiepojć i jeziora Przerośl, jak również Żytkiejmy. Do obszarów o słabym stopniu atrakcyjności zaliczono część północno-wschodnią gminy, w części południowej jeziora Niskie i Wysokie oraz nieliczne tereny na skraju Puszczy Rominckiej.

\subsection{PERCEPCJA TURYSTÓW}

Inaczej wypadła waloryzacja z punktu widzenia turystów, których znajomość obszaru gminy jest zdecydowanie słabsza. Wymienili oni 14 walorów. Podobnie jak w poprzednim przypadku, wyróżniającym się walorem (podanym przez 81,9\% respondentów) były mosty w Stańczykach, zaś drugim mentioned many times had high scores demonstrating a high level of attractiveness; qualitative features were not considered. The score for each resource mentioned was marked in its place on the map grid and if there were more than one, the scores were combined. In this way maps were drawn reflecting the perceptions of inhabitants and tourists (figs $5 \& 6$ ).

\subsection{GMINA INHABITANT PERCEPTION}

All in all the inhabitants mentioned 36 resources in Dubeninki gmina. The old railway viaducts in Stańczyki were mentioned most frequently $193 \%$ of respondents) while Romincka Forest was also highly evaluated (40.1\%), and these two resources largely determined the distribution of attractiveness. Within Romincka Forest nature reserves and Kaiser Wilhelm's boulders were additionally distinguished diversifying the attractiveness of this area.

The highest score (181) was found in square E8 covering Stańczyki and a part of the Bledzianka ravine, while D11 was also very highly evaluated (125 points) due to the proximity of Lake Pobłedzie and Romincka Forest. The areas of very high attractiveness were situated in areas of the forest including nature reserves, Kaiser Wilhelm's boulders and the Błędzianka ravine, with the remaining forest areas considered highly attractive. Areas of medium attractiveness were the regions of Lake Czarne, Dubeninki, Kiepojcie and Lake Przerośl, as well as Żytkiejmy, and low attractiveness the northeastern part of the gmina, Lakes Niskie and Wysokie in the south and some areas on the edge of Romincka Forest.

\subsection{TOURIST PERCEPTION}

The evaluation from a tourist point of view was different and their knowledge of the gmina was definitely poorer. They mentioned 14 resources and as above. the most frequent were the viaducts in Stariczyki (81.9\%), followed by Romincka 
Puszcza Romincka (w 30,6\% ankiet). Wpływ na ocenę końcową waloryzacji miały przed wszystkim te dwa walory.

Najbardziej atrakcyjnym obszarem, podobnie jak w poprzednich klasyfikacjach, jest pole E8, ze Stańczykami (67 punktów). Tereny o bardzo dużej atrakcyjności obejmują dwa pola sąsiadujące z polem E8, w których o atrakcyjności zadecydowały tereny leśne oraz rynna Błędzianki. Tereny o dużej atrakcyjności objęły $34 \%$ obszaru gminy. Sa to tereny Puszczy Rominckiej, z wyłączeniem pól, które zostały zaklasyfikowane do kategorii wyższych. Za średnio atrakcyjny turystycznie uznano rejon Kiepojć i jeziora Przerośl. Do terenów o małym stopniu atrakcyjności zaliczono rejon jezior Czarnego, Niskiego i Wysokiego, Żytkiejmy i okolice, trójstyk, rejon jeziora Mauda oraz teren dawnej wsi Golubie.

\section{WNIOSKI}

$\mathrm{Z}$ analizy map waloryzacyjnych wynika, że walory przyrodnicze obszaru gminy Dubeninki w głównej mierze determinuja jego atrakcyjność turystyczna. Spośród nich na pierwszy plan wysuwają się walory $w$ postaci dużego kompleksu leśnego oraz znacznych deniwelacji terenu związanych z polodowcowym typem krajobrazu (rynny polodowcowe), jak również walory w postaci jezior. Zauważa się jednak pewną rozbieżność w ocenie stopnia atrakcyjności jezior dokonywanej przez autorkę pracy a respondentów. Potencjalna atrakcyjność przyrodnicza jezior mierzona metodą bonitacji punktowej jest znacznie wyższa niż ich atrakcyjność w postrzeganiu mieszkańców i turystów. Rozbieżność tę można łatwo wytłumaczyć. Dokonując zobiektywizowanej oceny atrakcyjności teren gminy postrzegany jest jako zamknięty obszar. Nie uwzględnia się tu terenów sąsiadujących, które są konkurencyjne pod względem stopnia jeziorności. W postrzeganiu respondentów, jeziora występujące poza granicami gminy (szczególnie często wymieniane jeziora: Boczne, Gołdap, Rospuda i Hańcza) wypadają bardziej korzystnie niż akweny znajdujące się na badanym przez autorkę terenie. O wyższym stopniu atrakcyjności decyduje znacznie większa ich powierzchnia bądź bardziej atrakcyjne krajobrazowo położenie.

Drugim elementem, na który należy zwrócić uwagę, jest zróżnicowanie stopnia atrakcyjności w obrębie Puszczy Rominckiej. Zróżnicowanie to
Forest $(30.6 \%)$, which determined the final evaluation.

The most attractive area, as before, is square E8 with Stańczyki (67 points) while the two squares adjacent to it were rated 'very highly attractive' because of the forests and the Błedzianka ravine. 'Very highly attractive' areas covered $34 \%$ of the gmina including parts of the Romincka Forest, with half classified as 'high'. The regions of Kiepojcie and Lake Przerośl were of medium attractiveness, while Lakes Czarne, Niskie and Wysokie, Żytkiejmy and its vicinity, the region of Lake Mauda as well as the area of the former village of Golubie were considered of low attractiveness.

\section{CONCLUSIONS}

The evaluation maps show that the natural resources of the gmina of Dubeninki largely determine its tourist attractiveness. The most significant are the large forest complex and the considerable changes level in the postglacial landscape (postglacial gullying) as well as the lakes. However, there is a discrepancy in the evaluation of the attractiveness of the lakes between the author and the respondents. Their potential natural attractiveness, measured by the ranking method, is much higher than that perceived by local inhabitants and tourists but this discrepancy can easily be explained. Making an objective evaluation of attractiveness, the gmina is considered a closed area and neighbouring areas, competitive in terms of lakes, are not taken into consideration. In the respondents' perception, lakes outside the gmina borders (Boczne, Goldap, Rospuda and Hańcza) are more attractive than those inside because they are larger or set in a more attractive landscape.

Another important element is the diversified attractiveness within the Romincka Forest area itself clearly 
jest dobrze widoczne zarówno na wykonanej przez autorkę mapie waloryzacji, jak również na podstawie wypowiedzi mieszkańców. Waloryzacja opierająca się na percepcji turystów natomiast nie różnicuje wewnętrznie obszaru puszczy. Wynikać to może z faktu, że znajomość puszczy przez turystów jest stosunkowo słaba, dlatego traktują oni obszar puszczy jako jednolity kompleks leśny, nie dostrzegając $w$ jego obrębie bardziej i mniej atrakcyjnych terenów.

Elementem przyrodniczym, który we wszystkich typach waloryzacji uzyskiwał wysokie wartości jest odcinek rynny polodowcowej między Wysokim Garbem a Będziszewem, wykorzystywanej obecnie przez rzekę Błędziankę.

Spośród walorów pozaprzyrodniczych wszystkie grupy oceniające nadawały wysoką rangę mostom w Stańczykach, a następnie mostom w Kiepojciach. Atrakcja w postaci dawnej linii kolejowej i budowli z nią związanych (dworce, wiadukty, mosty) zauważana była we wszystkich waloryzacjach. Świadczy to o dużej unikatowości tego typu waloru.

Rozbieżności pojawiły się natomiast w przypadku oceny pozostałych zabytków architektury i budownictwa, w szczególności Dubeninek i Żytkiejm. Tereny tych dwu wsi wypadły bardzo korzystnie w waloryzacji turystyczno-antropogenicznej, zaś zdecydowanie słabiej w waloryzacji zindywidualizowanej. Świadczyć to może o ich faktycznie dużej atrakcyjności względem pozostałych wsi na terenie gminy, lecz stosunkowo niskiej względem miejscowości położonych poza jej granicami, na obszarze Suwalszczyzny czy Mazur.

Reasumując należy podkreślić fakt, że o atrakcyjności gminy Dubeninki decydują w największym stopniu mosty kolejowe w Stańczykach, ukształtowanie powierzchni i lesistość. Należy również zwrócić uwagę na wyodrębnienie się jednego wyraźnego podobszaru o wybitnych walorach turystycznych, na którym występuje nagromadzenie wielu interesujących elementów krajobrazu naturalnego i antropogenicznego, dobrze ze sobą współgrających.

\section{OCENA ZASTOSOWANYCH METOD}

Tematyka waloryzacji turystycznej, jak wiadomo, dotyka zindywidualizowanej percepcji człowieka, na którą oddziałuje wiele czynników o podłożu społecznym, kulturowym, czy psychologicznym. Badanie postrzegania krajobrazu, którego wyni- visible on the evaluation maps both of the author and the inhabitants. Evaluation based on tourist perception however does not distinguish this diversity, perhaps resulting from their relatively poor knowledge, and thus they treat it homogenously without noticing the more or less attractive parts.

The natural resource highly evaluated in both methods is the section of postglacial ravine between Wysoki Garb and Będziszewo, presently filled by the Błędzianka river. Among non-natural resources, both groups highly evaluated the viaducts in Stanczyki, followed by the bridges in Kiepojcie. The attraction of the former railway line and its related buildings (stations, viaducts and bridges) was identified in all evaluations, demonstrating the unique character of this type of resource.

Discrepancies occurred in the evaluation of the buildings of architectural interest in Dubeninki and Żytkiejmy in particular. The two villages were rated highly in the anthropogenic resource evaluation, but much lower that of individual perceptions. This may demonstrate their high level of attractiveness in comparison with other villages in the gmina, but relatively low in comparison with tourism destinations elsewhere in the Suwałki region (Suwalszczyzna) or Mazury.

In conclusion, it should be stressed that the attractiveness of the gmina of Dubeninki is determined above all by the railway viaducts in Stańczyki, followed by the landscape and the forest. This identification of a clearly distinctive area of exceptional tourist resources combines many interesting elements of the natural and anthropogenic landscape.

\section{EVALUATION OF THE METHODS APPLIED}

Human perception is affected by factors based on social, cultural or psychological background and thus creates difficulties in the evaluations of individual tourists. Studying landscape perception in order 
kiem ma się stać kartograficzne przedstawienie przestrzennego rozłożenia stopnia atrakcyjności danego terenu, jest zatem procesem skomplikowanym. O ile bazą wyjściową do badań jest percepcja człowieka, o tyle trudnym zadaniem jest uogólnienie i zobiektywizowanie ocen i wyników. Zaprezentowane metody stanowią próbę sprowadzenia cech jakościowych - niemierzalnych do konkretnych, porównywalnych wartości liczbowych.

Metoda bonitacji punktowej wykorzystana w pracy jest traktowana jako podejście względnie zobiektywizowane. Względność ta polega na doborze jednostek przestrzennych, w obrębie których pomiar będzie dokonywany, oraz umiejętności w doborze kryteriów, według których atrakcyjność będzie oceniana. Wybór geokompleksów jako jednostek podstawowych umoźliwia ocenę atrakcyjności fragmentów przestrzeni o zbliżonych cechach fizycznogeograficznych, co oznacza, że w całej rozpatrywanej jednostce stopień atrakcyjności będzie jednakowy. Z kolei sąsiadujące jednostki mogą cechować się skrajnie różną atrakcyjnością względem siebie. Z drugiej strony trudnością może okazać się odpowiednie wyłonienie geokompleksów w przestrzeni. Siatka pól geometrycznych w sztuczny sposób dzieli przestrzeń. Wprowadzony podział powoduje rozbicie obszarów w miarę jednolitych pod względem krajobrazowym na kilka jednostek podstawowych. W efekcie uzyskana wartość bonitacyjna może być zaniżona w stosunku do rzeczywistej atrakcyjności terenu. Przykładem zaistnienia takiej sytuacji jest rozdzielenie obszaru wsi Żytkiejmy lub Jeziora Czarnego na kilka pól. Dlatego przy dalszej analizie fakt ten należy brać pod uwagę.

W przypadku bonitacji zasadniczą kwestią jest ustalenie kryteriów oceny oraz przypisanie im wartości punktowych. Istotne znaczenie ma określenie rangi walorów przyrodniczych względem antropogenicznych. Na ostateczny wynik waloryzacji ma też wpływ ustalenie liczby i zakresu przedziałów bonitacyjnych.

Waloryzacja oparta na metodzie kwestionariuszowej bazuje na subiektywnych ocenach respondentów. Na wynik badań wpływa sformułowanie i dobór pytań w ankiecie oraz precyzyjność odpowiedzi, znajomość terenu, w tym orientacja na mapie osób ankietowanych. Autorka zauważyła, że respondenci najczęściej wskazywali interesujące obiekty powołując się na ich nazwę własną unikając umiejscawiania nie nazwanych walorów w przestrzeni lub na mapie. $\mathrm{Z}$ tego faktu można to cartographically present the spatial distribution of attractiveness is a complicated process. When human perception is the starting point in the research, it is difficult to generalise and objectify evaluations and results. The methods presented above are an attempt to express immeasurable qualitative features in the form of comparable figures.

The ranking method is treated as a relatively objective approach. This relativity lies in the choice of spatial units within which measuring is done, as well as an appropriate selection of criteria on which attractiveness is to be evaluated. The choice of basic units makes it possible to evaluate the attractiveness of areas with similar geographical qualities in which the attractiveness of the whole unit will be the same, but the attractiveness of adjacent units may widely differ. On the other hand, it may prove difficult to properly distinguish geo-complexes. A grid of geometrical squares divides space in an unnatural way splitting areas with a relatively homogenous landscape into several units. Both Żytkiejmy and Lake Czarne are divided between several squares and in fact the point scores may be lower than the actual attractiveness of an area. Therefore, in any analysis this should be taken into account.

In the ranking method it is essential that evaluation criteria are established and point scores calculated. It is also necessary to define the ranks of natural resources relative to anthropogenic ones. The final evaluation depends on the number of ranks and their point score ranges.

In questionnaire evaluation the phrasing and selection of questions is important as well as the respondents' precision and knowledge of the area, including their ability to read maps. The author observed that respondents frequently indicated interesting resources by naming them, and avoided placing those unnameable on the map. It may be assumed then that places which have proper names will be evaluated higher. 
by wysunąc hipotezę, że miejsca posiadające nazwy własne w waloryzacji będa wypadały korzystniej.

Przekładanie opinii respondentów na wartości mierzalne może nastapić w dwojaki sposób. Respondenci hierarchizują obiekty nadając im wartości liczbowe w zależności od ich atrakcyjności lub pod uwagę brana jest suma wskazań na dany walor w obrębie badanej grupy osób. Oba sposoby uważam za prawidłowe i zmierzające do miarodajnych wyników.

Interpretacja map waloryzacyjnych jest ostatecznym etapem badań. Pamiętać przy tym należy, że kaźda zmiana kryteriów, przedziałów bonitacyjnych bądź jednostek przestrzennych pociąga za sobą zmianę w wynikach. Niemniej jednak uważam, że zaprezentowane metody badawcze stanowią właściwą drogę do oceny stopnia atrakcyjności terenu, gdyż bazują na interpretacji porównawczej. Przy starannie dobranych, konsekwentnych założeniach mogą okazać się cennym źródłem do dalszej analizy.
Respondents' opinions can be transformed into measurable values in two ways. Respondents rank objects by allocating points depending on their attractiveness, while the number of times a given resource has been mentioned as belonging to a particular group is recorded. Both methods seem to be appropriate and reliable.

Interpretation of the evaluation maps is the final stage of the research, remembering that each change of criterion, point range or spatial unit will be reflected in a change of results. However, in the author's opinion the research methods presented above are an appropriate way to evaluate attractiveness because they are based on a comparative interpretation. Provided they are also based on well-selected, solid assumptions, they may be a valuable source of information for further analysis.

BIBLIOGRAFIA - BIBLIOGRAPHY

BARTKOWSKI T., 1965, Zagadnienia atrakcyjności środowiska geograficznego w Polsce dla wypoczynku (na wybranych przyktadach z. Niziny Wielkopolskiej), Sprawozdanie z Poznańskiego TPN za III i IV kwartał 1965, Poznań.

BARTKOWSKI T., 1969, Ocena atrakcyjności środowiska geograficznego na okotobattyckich obszarach pojeziernych od Skagerraku po jezioro Onega, Sprawozdanie z Poznańskiego TPN za l i II kwartał 1969, Poznań.

KondrackI J., 2002, Geografia regionalna Polski, PWN, Warszawa.

MARSZ A., 1970, Ocena srodowiska geograficznego rynny je zior Kórnicko-Zanimyskich dla potrzeb turystyki i wypo- czynku jako przyktad wykorzystania mapy ,uroczysk” do oceny w dużej podziatce, "Zeszyty Naukowe UAM", nr 71, „Geografia”, z. 9.

RADZIEJOWSKI J., 1979, Problem oceny środowiska geograficznego dla potrzeb turystyki, „Przegląd Geograficzny”, t. 51, z. 4.

WARSZYŃSKA J., 1970, Waloryzacja miejscowości z punktu widzenia atrakcyjności turystycznej (zarys metody), ,Zeszyty Naukowe UJ”, nr 249, „Prace Geograficzne”, z. 27.

WARSZYŃSKA J., 1974, Ocena zasobów środowiska naturalnego dla potrzeb turystyki (na przyktadzie woj. krakowskiego), „Prace Geograficzne”, z. 36. 